\title{
Foreign Direct Investment in State Owned Enterprises
}

\author{
Kyu-Hee Joo ${ }^{1}$, Hyoung Suk Shim ${ }^{2, *}$, Wonsik Sul ${ }^{3}$ \\ ${ }^{1}$ Investment Information Team \& Foreign Investment Policy Center, Korea Trade-Investment Promotion Agency, Seoul, Korea \\ ${ }^{2}$ School of Business, College of Staten Island, The City University of New York, 10314, New York, United States \\ ${ }^{3}$ Division of Business Administration, Sookmyung Women's University, Seoul, Korea
}

Copyright (C) 2017 by authors, all rights reserved. Authors agree that this article remains permanently open access under the terms of the Creative Commons Attribution License 4.0 International License

\begin{abstract}
We analyze determinants of foreign direct investment (FDI) in non-competitive industries. We develop a micro-level FDI determination model that allows for nonzero mark-up, and estimate it using the administrative FDI recipient records and annual financial statement data for Korean state owned enterprises (SOE). Using SOEs as our research objects can rule out the endogeneities of mark-up, firm ownership structure and the associated vertical or horizontal incentive FDI. This yields a consistent estimation of the effect of mark-up and other productivity-related factors on FDI. From the empirical analysis, we find that FDI is more likely to flow into firms with large-scale physical capital and output, and a positive mark-up, and the effect is the inverse of the number of workers in the firms, which implies that FDI might not cause productivity spillover effect in non-competitive industries.
\end{abstract}

Keywords Foreign Direct Investment, State Owned Enterprises, Public Sector Pricing, Productivity Spillover

\section{Introduction}

In this study, we seek an answer to the question: what motivates foreign investors to invest in a specific domestic firm, if firms do not need to improve its productivity for realizing positive profit and the associated investment return. We derive a new foreign direct investment (FDI) determination model that allows for nonzero mark-up, and examine the mark-up's effect on FDI. We then estimate the model using the administrative FDI recipient records of Korean state owned enterprises (SOE). Analyzing SOE's FDI records allows to obtain statistically consistent estimates by ruling out endogenous mark-up and SOE's ownership structure that are associated with horizon and vertical incentive FDI. The emprical analysis of FDI in SOEs, moreover, does not require the competitive market assumption, and we can analyze the role of market competitiveness on FDI determination.

This question about FDI's motivation naturally arises from current FDI studies such as Wang and Wang [30], which ar- gue with a micro-level data analysis that FDI has no statistically significant productivity improvement. They use Chinese firm level data for about 125,000 private firms and SOE per year from 2001 to 2007 and performs a firm productivity equation estimation with foreign ownership and FDI. Wang and Wang [30] find no evidence of productivity improvement caused by foreign ownership. This study draws a skeptical conclusion about the productivity improvement as a major channel of realizing positive FDI return, which is made by decreasing production cost at a given market price. The study further shows that the emprical result is consistent over the type of firms whether it is a private firm or a SOE, and the different measures of firm productivity.

The other channel is through mark-up, which is made by increasing market prices given production cost. Sembenelli and Siotis [25] analyzes the channel with micro-level data. They use domestic and foreign firms in Spain from 1983 to 1996 to perform a 'profit-cost margin' equation estimation, where the margin is a proxy measure for mark-up, and find that FDI increases mark-up in the long-run and foreign presence reduces mark-up in the short-run, but this effect of foreign presence shrinks overtime. Sembenelli and Siotis [25]'s analysis implies that, for foreign investors, FDI return through productivity improvement may not be attractive than mark-up. This seems to be true, if the productivity improvement is costly, whereas mark-up is just given by the domestic firm's market power.

Given these two findings, the next step is to examine simultaneously at the micro-level, the extent to which foreign investors' FDI decisions are determined by domestic firms' potential mark-up and potential productivity improvements. However, recent studies on determinants of FDI have used aggregate level data such as bilateral FDI or industry-wise FDI. Blonigen [3] provides a comprehensive survey of the empirical literature on FDI determinants, and argues that the gravity model sufficiently explains bilateral FDI data. Bergstrand and Egger [2] develops an extended knowledge-capital model that explains a multinational enterprises (MNE)' international trade and FDI decisions. The model is based on the argument from Blonigen [3], and the authors perform the gravity estimation for the 
model. Eicher et al [14] and Blonigen and Piger [4] develop Bayesian estimation of the gravity model to rule out selection bias and model mis-specification that cause inconsistency of their econometric estimations.

Clearly needed is a micro-level FDI determination model which also relaxes the competitive market assumption and allows firms to have positive excess profit so the foreign investor can earn positive excess investment return. However, positive excess profit for a firm in a non-competitive industry is obviously endogenous, because the firm is no longer a price taker, it is rather a price maker who can influence the market price by adjusting their quantity supplied to obtain maximum positive profit. Econometric model estimations with the competitive market assumption, which do not control for this endogeneity, may then yield biased and inconsistent result.

The other critical issue for developing the model is ownership structure. The seminal works in MNE and foreign investment theory by Helpman [15], and Markusen [22] distinguish between horizontal and vertical incentive FDI, arguing that the vertical incentive FDI aims to improve the domestic firm's productivity by reducing total production cost, whereas the firm with horizontal incentive FDI is motivated by improving its sales performance. The differing motivations for FDI needs to be ruled out, or at least controlled for micro-level econometric estimations of FDI determination.

We choose SOEs to examine FDI determination at the micro-level, for the purpose of making a fair comparison between the effect of productivity improvement and mark-up profit on FDI. We derive a FDI determination model by utilizing the SOE's regulated pricing, and the ownership structure. The advantage of the FDI determination model is that the associated econometric model can consistently estimate the effect of productivity improvement and mark-up on FDI, for two reasons. First, SOEs have no the vertical incentive FDI and the other corporate governance issues because its ownership and managerial decisions belong to the government. The only theoretical motivation for FDI remains is to improve the recipient domestic SOE's productivity. Second, SOE's regulated pricing yields predetermined mark-up, a positive excess profit, and the associated investment return. SOEs normally exercise the regulated pricing to protect its industry from monopoly pricing due to SOEs economies of scale, and therefore, the government regulates its pricing at a fixed level.

We begin with analyzing market concentration of Korean industries. The regression analyses for market concentration indices show that industries with SOE and privatized SOE are more likely to be concentrated than other industries without SOE. We then perform econometric estimations for the FDI determination model that we derive based on the SOE's characteristics. We find mark-up, which is given before investment decisions are made, has a strongly significant and positive effect on FDI, and the FDI is more likely to flow into a firm with large production output, physical capital stock and investment, and less likely to flow into labor intensive firms. The empirical findings indicate that foreign investors prefer to invest in domestic firms with large capital, mark-up profit, and a small labor force, and this implies that FDI might not cause productivity spillover effect in non-competitive industries.

The organization of this paper is as follows: First, we review the history of Korean SOE and FDI, and the associated government policies in section 2. Then we review theory of public sector pricing as an element in developing the FDI determination model for $\mathrm{SOE}$ in section 3 . We derive an empirical model for FDI in SOE at section 4. In section 5 the regression analyses of market concentration indices, and econometric estimations for the FDI determination model are presented.

\section{FDI and State Owned Enterprises in Korea}

In this section, we briefly discuss distinguishing features of FDI and SOE in Korea, and examine whether economic analyses of Korean FDI and SOE can be generalized to the other countries' FDI and SOE. First, we introduce and review the history of Korean FDI and the associated government policies. Then we outline the history of the Korean SOE, how they are categorized by the Korean government, and the associated government policies. Finally, we briefly discuss characteristics of privatized Korean SOE.

\subsection{Foreign Direct Investment in Korea}

The Korean economic growth rate from the 1960's to mid 1990 's is 6.2 percent per year with a relatively low inflation rate and small size of domestic market. The growth rate was driven by rapid expansion of international trade, especially the rapid growth of exports, and has often been referred to as a miracle. ${ }^{1}$ In the mean time, foreign investment inflow to the Korean domestic firms grew fast but the trend changed around 1998 at the time of the Asian financial crisis, the Korean economy faced a recession due to the depletion of foreign currency, which drastically reduced economic growth in the first decade of the 2000s.

After the foreign currency crisis, the Korean government implemented several policies introduced to stimulate foreign investment in domestic firms. The Foreign Investment Promotion $\mathrm{Act}^{2}$ defines FDI as foreign investment in corporations of the Republic of Korea to purchase capital stocks or stock shares to participate business activities, and hold permanent relationship with the corporations. Foreign investors who satisfy those criteria are eligible to apply for the foreign investment benefit package of corporate income tax reduction that consist of five years of complete tax relief, plus 50\% reduction after three years of local government tax, access to an exclusive public services. The package also includes use

\footnotetext{
${ }^{1}$ For example, Lucas [19] takes Hong Kong, Korea, Singapore and Taiwan as an example of rapid economic growth, and refers to Korean economic growth as a miracle to emphasize its distinctive feature.

${ }^{2}$ The Foreign investment Promotion Act is one of the most notable policy that specifies foreign investment activities into several categories and manage it. The act was activated November 17 th of 1998, when the Korean economy faced foreign currency crisis. The act is aim to support and promote foreigners who invest Korean domestic corporates and companies significant amount under the relatively long-term contract.
} 


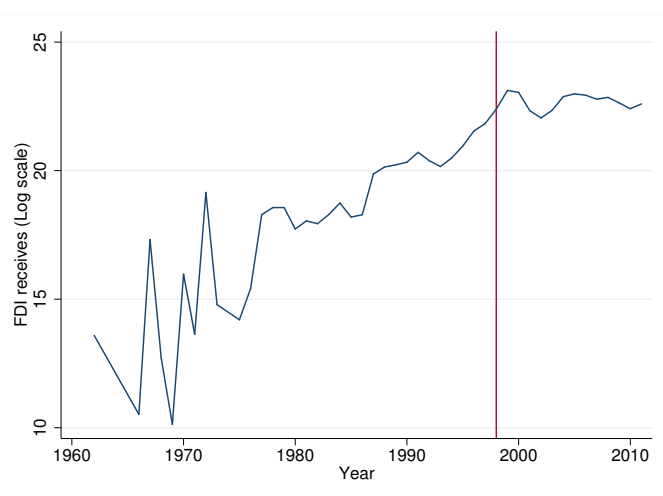

(a) All Firms

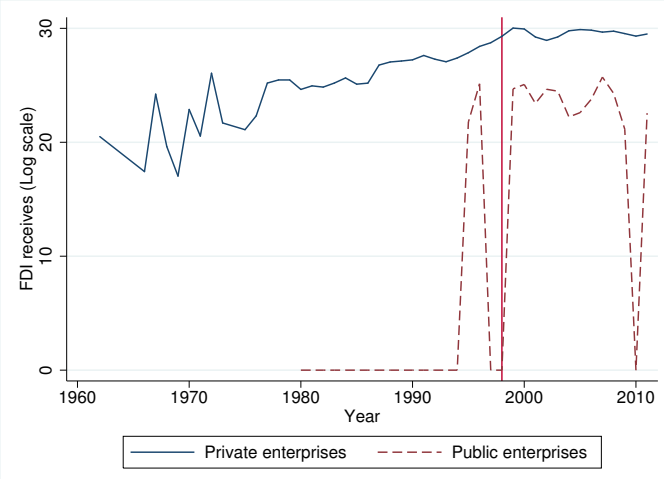

(b) Private and Public Firms (SOE.png)

Figure 1. Inward FDI into Korean Firms

of government real estate assets without additional payment for greenfield types of investment projects.

By the definition of FDI in the promotion act, the foreign investor can be either the investor's company itself, or its parent company or the parent company's shareholders who lend loans to the foreign investment company under a sufficiently long-term contract, at least five years. FDI made by purchasing corporate stocks qualifies foreigners whether 1) own common stocks of corporations and companies in Rep. of Korea make up more than $10 \%$ of total equity of the company, and exercise voting rights, or 2) own common stocks that is less than $10 \%$ of the total equity, but whose participation in business activities can be prove by officially documented contracts. In addition, FDI in Korean corporations falls in four different categories: 1) establishing a new business, or purchasing stock warrants, 2) purchasing common corporate stocks, 3) long-term loan, and 4) mergers and acquisitions.

Figure 1 is time plots for the aggregate inward FDI. The left panel of Figure 1 presents the time trend of the inward FDI in public and private Korean firms. FDI gradually increases until 1998, then it plateaus. The volatile trend during 1960 s to the middle of 1970 s to foreign investors preferring a one-shot investment during this time period. The relatively stable upward trend after the 70s is then due to the change of the preference to sequential investment because of the steady and fast economic growth. The right panel is separate time plots for FDI private firms and SOE. Note that the vertical line at 1998 indicates a hypothetical breakpoint for foreign currency crisis. FDI dynamics for private firms seems to follow the general tendency of the aggregate FDI series, whereas FDI in SOE, the dashed line, begins in the middle of 1990 , then seems to stay constant. Overall, the FDI in SOE's time trend seems to be identical to the aggregate FDI time trend for both private and public firms.

\subsection{State Owned Enterprises in Korea}

SOE in Korea have played a crucial role for the rapid economic growth of the second half of the $21^{\text {th }}$ century. After achieving independence from Japanese colonization in 1945, the Korean government took over most of the Japanese busi- ness entities and began to operate them. From the 1960s, the government had utilized SOE for its central planning, promoting exports with strong industry protection and government subsidies. In the late 80 s, this central planning policy was shifted toward market oriented policies such as opening stock shares in markets, its privatization, and so on. After the foreign currency crisis in 1997, many SOE were gradually privatized as part of recovery and restructuring of the Korean economy.

Recently, the government categorizes SOE based on their size, and evaluate their performance and efficiency. In 2007, the Ministry of Finance enacted the Public Institute Operating Act to distinguish necessary and unnecessary public owned institutes in every year of January, and evaluate the necessity for government funding. In addition, the Ministry of Finance classifies public owned institute into four categories with different criteria and operational goals such as proportion of government funding, out of the SOE's entire revenue in a fiscal year. SOE are divided into "market oriented SOE" and "semi-market oriented SOE". Market oriented SOE of the total proportion of operating revenue in a year is greater than $85 \%$, the number of employees is greater than 50 , and total assets owns are worth more than two trillion won (\$ 1.4 billion in USD PPP). The semi market oriented SOE is a SOE that earns annual revenue that consists of more than $50 \%$ of operating revenue. In January 2011, there were 14 market oriented SOE that operate in industries such as gas, petroleum oil, local heating, and airports, and 13 semi-market oriented SOE within mining, highway and railway.

\subsection{Privatized State Owned Enterprises in Korea}

Privatization of Korean SOE mostly occurred in president Dae-Jung Kim's administration from 1998 to 2002, although every presidential administration, since it has announced a list of SOE to be privatized as part of their economic policy agenda. Political conflict has generally impeded privatization but not in Kim's administration due to the Asian financial crisis. Since public owned institutes supply goods and services to their domestic economy under regulated prices, the SOE became a significant source of increasing government deficit. 
Therefore, president Kim and his administration were able to plan to privatizing 11 parent SOE and their 77 sister companies, and implemented it for 8 parent SOE and their 66 sister companies during that time without facing severe political debate. The privatized SOE are electricity, road and highway, housing, water resources, telecommunication, tobacco, natural gas, heavy industry, and so on.

Table 1 presents the list of SOE that have received FDI more than once. There are only two SOE, which have never been privatized, and the rest of SOE have received FDI after privatization. The only exception is Asiana Airlines. It received 172,000 U.S dollars before privation, $0.2 \%$ of the total amount, then 80,000,000 U.S dollars received after privatization. This fact reflects that privatized SOE are preferable to non-privatized SOE, and the reason would be the monopoly profit, which we will discuss later.

Table 1. FDI receipts of Korean State Owned Enterprises

\begin{tabular}{lccc}
\hline \hline \multirow{2}{*}{ Company Name } & \multirow{2}{*}{ Group Name } & $\begin{array}{c}\text { PrivatizationFDI receipts } \\
\text { (Year) }\end{array}$ & $(1,000$ USD) \\
\hline Asiana Airlines & Gumho Asiana Group & 1999 & $80,172,000$ \\
KEPCO-Uhde Inc. & KEPCO corp. & No & $5,508,184$ \\
OKYC CO., LTD & Korea National & No & $3,638,394$ \\
Korea Ratings & Oil Corporation & 1999 & $91,967,805$ \\
KT corp. & Korea Ratings & 2002 & 3 \\
Posco Energy & KT corp. & 2001 & $42,000,000$ \\
Posco Terminal & Posco & 2001 & $11,889,152$ \\
SNNC. CO.LTD & Posco & 2001 & $102,479,362$ \\
POSCO-Nippon Steel & Posco & 2001 & $12,796,494$ \\
RHF Joint Venture & Posco & & \\
Samsung Total & Samsung & 1995 & $5,213,000$ \\
Petrochemicals & Sejong group & 1999 & $191,505,124$ \\
Sejong Telecom & \multicolumn{4}{c}{ Notes: FDI receipts is the total (nominal) amount of FDI that have } \\
been received from 1960 to 2011, in U.S. dollar. KEPCO-Uhde \\
Inc., and OKYC CO., LTD with the reported privatization year \\
\multicolumn{2}{c}{ "No" have never been privatized SOE. }
\end{tabular}

\section{Theory of State Owned Enterprises: Literature review}

In this section, we review previous literature on the role of SOE in international business and public finance. The main goal here is to develop and support the argument that the SOE's operating profit and the associated investment return are exogenously given, in order to justify the statistical consistency of our empirical analysis. We thus review public sector pricing theory for the SOE and employ it to develop an econometric model for FDI in the later chapter.

\subsection{Role of State Owned Enterprises}

Vernon [29] proposes the definition and the role of SOE, on the international business perspective that SOE is a tax collection agency by producing and selling goods and services to the public, and it is expected to lead an industries productivity growth. Moreover, the SOE play a role in international markets that stimulates international trade by competing with foreign firms and generating a trickle down effect on the other domestic firms in the same industry. Therefore, the international role of SOE leads domestic firms to becoming more competitive in international market. The role of SOE, as proposed by Vernon [29], seems to be conflicted with the goal for SOE as a public institution. SOE rather plays a role to maximize social welfare, that is to achieve an efficient allocation of scarce resources to all in its economy, than maximize its own profit, for the reason which we now explain.

In order to be a competitive firm in international market, the SOE requires scarce resources that are then unavailable to private firms. This prioritizing the resource consumption is the main reason that the SOE needs to be treated as a public institution, even we consider its role and performance in international trade. Bös [5] defines SOE as public enterprises, which produce public utilities such as energy, communication, and transportation, or operate in basic goods industries such as finance, agriculture, health and education. Public enterprises have generally been regulated in their market activities to sell goods and services, according to Bös [5], in order to protect the economy from market failure, and most of the regulations imposing on prices of the public enterprises' goods and services because the market failure is for SOE to behave as monopolies in their industry.

\subsection{Public Sector Pricing}

Public enterprises operate under a specific pricing strategy regulated by the government to protect from monopoly pricing. Bös [5] provides a comprehensive summary of the major three public sector pricing schemes, which are well representing the SOEs' pricing strategy. The first is marginal cost pricing, which is a pricing that charges consumers only the marginal production cost of public enterprises' goods and services. The second is Ramsey pricing an optimal pricing for a particular industry comprised of both public and private enterprises producing a homogenous good or service, where the price regulation can be imposed only on the good or service, produced by the public enterprise. Note that Ramsey pricing calculats the price of the public enterprises' good or service by considering demand for both public and private enterprises' good or service simultaneously.

These two widely known public pricing schemes are neither realistic, nor feasible. Marginal cost pricing can take place any quantity supplied, so that it is too ambiguous to be used as a consistent pricing strategy, also the price cannot stay constant if the SOE's marginal production cost is not invariant. Furthermore, the price of good, given by marginal cost pricing, has to be lower than $p$, the competitive price and the SOE cannot avoid deficits if the price is lower than average total cost. Ramsey pricing is also unrealistic for SOE because the demand for goods, produced by both public and private enterprises, is observable to the SOE. It is thus hard to think that SOE, as public enterprises, set their price based on their own prediction, which might yield inconsistent pricing.

For these reasons, the most feasible and realistic pricing strategy is rate of return regulation. This pricing strategy to keep the public enterprises' rate of investment return (ROI) constant. The rate of return regulated pricing is both flexible with respect to changes in production costs, and provides positive investment return for the investors, so the SOE do 
not necessarily generate deficits which the government has to subsidize. Because of the positive and stable investment return, in addition, this pricing makes SOE a very attractive investment object, compared with conventional financial instruments such as stocks, bonds, and currency exchange. So the SOE are able to generate capital investment if the rate of return guarantees an amount which is at least higher than risk-free market return.

Figure 2 represents public sector pricing graphically. As we reviewed also, public enterprises produce goods and services asmonopolies so the demand curve, $\mathrm{D}$, has a downward slope. By producing $y^{* *}$, the monopoly firm is able to earn the highest revenue, $p^{* *}$ times $y^{* *}$. If the government exercises marginal cost pricing, there are two possible outcomes. If the regulated price is less than $p$, the competitive price, then the firm generates a loss, which has to be subsidized by the government. If the price is greater than $p$, on the other hand, the firm makes positive profit, which can be either reinvested, or taxed by the government.

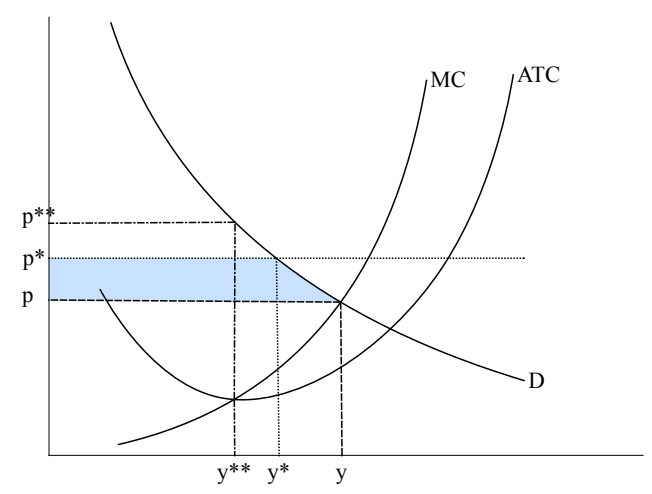

Figure 2. Public Sector Pricing

The main difference between marginal cost pricing and ROI fixed pricing is whether the SOE can adjust its profit and the associated investment return with respect to the changes in factor prices over time. For public enterprises with marginal cost pricing, the amount of profit is determined by marginal cost curve, which represents production technology of firms, even though the government regulates the price. Therefore, the SOE can make more profit by reducing their marginal cost schedule, which is not necessary to improve their productivity. ROI fixed pricing, however, considers the demand condition and marginal cost condition simultaneously so that the firms can keep their profit constant. The shaded region in the figure 2 indicates profit that is given by ROI fixed pricing. This implies also that stable return for investors is guaranteed, given the time variant marginal cost that is uncertain for the investors.

\section{FDI on State Owned Enterprises: A Model}

In this section, we derive a model for FDI determination under the specific condition where the investment target firm is a SOE. We design the model based on the assumptions that i) The ownership of a SOE cannot be changed even though its stocks are traded in the market, ii) the government regulates the SOE's pricing, so operating profit and the associated investment return are predetermined, and iii) foreign investors face their own uncertainty for the market price due to interest rate and exchange rate parity between the SOE's home country and host country changes in government pricing. We then propose an econometric model that is an empirical form of the FDI determination model with micro-level FDI data.

\subsection{Theory of Foreign Investment in SOE}

The purpose of deriving a new FDI determination model is to estimate the effect of mark-up and productivity factors on FDI at firm level, and compare the effects to see which is more important to bring more FDI to a firm. The most difficult challenge in this empirical analysis is to estimate the effect of mark-up on FDI consistently because a firm is obviously able to change its mark-up profit by adjusting quantity supplied unless the market is in perfect competition. We choose SOE whose operating profit is regulated by the government, and thus, its mark-up is predetermined, or exogenously given. In addition, the SOE's ownership cannot be changed so that we can rule out the role of corporate governance and vertical incentive FDI, where a foreign company or multinational invests in a domestic firm to produce intermediate goods for their final output production.

The marginal return for FDI investors in the SOE, under this condition, is given by the price differential between the regulated price and marginal cost of producing a good. But it depends also on exchange and interest rate parities between the host and the investor countries. Since the SOE pays production cost using domestic currency, the exchange rate parity would affect only on the regulated price, so it determines marginal foreign investment return. ${ }^{3}$ Finally, the change in the regulated price and exchange rate parity in the future are unobservable to the investor so she treats it as an uncertain factor that she predicts by her own forecasting rule. ${ }^{4}$ Under assumption 1), we construct the SOE's present value profit maximization problem:

$$
\begin{array}{r}
\max _{K_{t+1}} E\left[\sum_{t=0}^{\infty} \beta^{t}\left\{D\left(y_{t}, u_{t}\right)-c\left(y_{t}\right)\right\}\right], \\
\text { s.t. } y_{t}=f\left(K_{t}, L_{t}\right) \\
I_{t}=K_{t+1}-\delta K_{t}
\end{array}
$$

where $D\left(y_{t}, u_{t}\right)$ is total revenue that is a function of output $y_{t}$ and uncertain demand shift $u_{t}, c\left(y_{t}\right)$ is total cost, and $f\left(K_{t}, L_{t}\right)$ is production technology, a function of capital and labor input. The firm chooses the optimal $K_{t+1}$, the amount of future capital input that maximizes the present value of its profit.

\footnotetext{
${ }^{3}$ Assume that the firm, SOE, produces a single good or a service so that its marginal cost can account for obtaining profit.

${ }^{4}$ In the economics and theoretical corporate finance literature, the uncertainty is represented by a random variable for static model, and a stochastic process for dynamic model. Firms' forecasting rules are thus represented by the mathematical expectation. We will use this specification later in this chapter.
} 
Now we consider a new price $p^{*}$ in which the foreign investor recognizes to account for her marginal profit. As we discussed $p^{*}$ depends on unobservable government pricing, exchange rate and interest rate parities, so we assume that it is a function of unobservable price change $u_{t}^{*}$ and denoted it by a function $p^{*}\left(u_{t}^{*}\right)$. Assume also that the production technologies is constant return to scale. Then the foreign investment return maximization problem is the following:

$$
\begin{aligned}
\max _{k_{t+1}} E\left[\sum_{t=0}^{\infty}\left(\beta^{*}\right)^{t}\left\{p^{*}\left(u_{t}^{*}\right)-c\left(y_{t}\right)\right\} \cdot y_{t}\right], \\
\text { s.t. } y_{t}=f\left(k_{t}\right) \\
I_{t}^{*}=k_{t+1}-\delta k_{t}-I_{t}
\end{aligned}
$$

where $I_{t}^{*}$ is foreign investment and $I_{t}$ becomes domestic investment, $k_{t}$ is the capital-labor ratio, $K_{t} / L_{t}, \beta^{*}$ is the discount rate for the foreign investor that reflects interest rate parity. Note that $p^{*}\left(u_{t}^{*}\right)$ and $c\left(y_{t}\right)$ can be thought of as average total revenue and average total cost respectively, and since $p^{*}\left(u_{t}\right)$ does not depend on output, represented by $f\left(k_{t}\right)$, it is equal to marginal revenue. By assuming $u_{t}^{*}$ is a stochastic process with Martingale property, ${ }^{5}$ the maximization problem becomes a standard dynamic stochastic programming and the solution is the optimal future capital input $k_{t+1}$ that maximizes a value function:

$$
\begin{aligned}
v\left(k_{t}, u_{t}^{*}\right) & =\max _{k_{t+1}}\left\{p^{*}\left(u_{t}^{*}\right)-c\left(f\left(k_{t}\right)\right)\right\} \cdot f\left(k_{t}\right) \\
& +\beta^{*} \int v\left(k_{t+1}, u_{t+1}^{*}\right) Q\left(u^{*}, d u^{*}\right)
\end{aligned}
$$

where $Q\left(u^{*}, d u^{*}\right)$ is a transition density of $u_{t}^{*}$, which is a probability distribution function of $u^{*}$ over time. Because the investor does not have exact information about the firm's production technology, production cost, and the transition density of uncertain factors on the price, deriving an exact closed form from (4.1) is not relevant. However, we can exploit a simple testable model in which the FDI decision on the firm is determined by variables in the value function (4.1).

\subsection{Empirical Model}

Let $I_{t}$ be FDI in a SOE. From the value function (4.1), $I_{t}$ can be determined by which the investor chooses to maximize the discounted future profit with respect to capital accumulation, $k_{t+1}=I_{t}^{\prime}+\delta k_{t}$, where $I_{t}^{\prime}$ is investment from the domestic financial market. ${ }^{6}$ For given capital depreciation rate $\delta$ and the current capital accumulation, the future period capital accumulation level is determined by the investment decision $I_{t}$, so it is the solution of (4.1). Since $I_{t}$ is derived under the foreign investor's maximization problem, and it purchases capital stock, it is relevant to treat $I_{t}$ as FDI at

\footnotetext{
${ }^{5}$ Martingale property of a stochastic process is that the future realization of the stochastic process depends only on the current realized value, not the past. This property is a necessary condition to solve discrete dynamic optimization problem under uncertainty because the dynamic system link only two time points. It can be interpreted simply as the efficient market hypothesis, or random walk hypothesis about exchange rate parity $u_{t}^{*}$

${ }^{6}$ Because $k_{t}$ is capital-labor ratio, we can think the investment $I_{t}^{\prime}$ as a rate of investment, out of the current level of capital accumulation $K_{t}$.
}

t. This leads to suggest a hypothetical linear model for FDI, which is observable as:

$$
\begin{aligned}
I_{t} & =\beta_{0}+\beta_{1} \cdot\left(A T R_{t-1}-A T C_{t-1}\right)+\beta_{2} y_{t} \\
& +\beta_{3} k_{t}+\beta_{4} l_{t}+\beta_{5} \cdot I_{t}^{\prime}+u_{t}^{*},
\end{aligned}
$$

where $A T R$ and $A T C$ are average total revenue and total cost respectively, $I_{t}^{\prime}$ is investment from the domestic financial market. Because the FDI decision is made by forecasting $\beta^{*} E\left[\nu\left(k_{t+1}, u_{t}^{*}\right)\right]$, the expected future profit, a lagged value of profit measure $A T R_{t-1}-A T C_{t-1}$ would be natural for current FDI decision model. The remaining variables are control variables for production technology and the associated production cost, and the SOE's capital accumulation and investment status in domestic market.

\section{Empirical Analysis}

In this section, we introduce the Korean FDI and firm level financial statement data that we use for the empirical analysis. We then present market concentration statistics to show industries with SOE are more likely to be concentrated in terms of market share, and the consequences of the SOEs' privatization. Finally, we present the estimation of (4.2) to demonstrate distinctive factors of $\mathrm{SOE}$ and privatized $\mathrm{SOE}$ that attract FDI.

\subsection{Data}

FDI data set that we use an administrative record of foreign investments in Korea, provided by the ministry of trade, industry and energy. ${ }^{7}$ The records contain information about domestic recipients, foreign investors, types and amounts of the transactions in U.S. dollar, etc, collected from 1962 to 2011, 28,382 investors were located in 122 countries, and they invested in 23,533 domestic business entities. The total number of records is therefore 47,823 . This FDI data has been recorded on daily basis, so we aggregate FDI amount by the domestic business entities and year. Then we merge the data with the Korean firms' annual financial statement data, provided by National Information \& Credit Evaluation's corporate financial statement database (kisvalue). ${ }^{8}$

Using the financial statement data, we create economic variables such as output, total revenue, total cost, labor input, (physical) capital input, and investment according to the standard methodology proposed in National Income and Productivity Account (NIPA [28]), written by U.S. Bureau of Economic Analysis. According to NIPA [28], a firm's output in a fiscal year can be measured by sales plus changes in inventories, and subtract intermediate goods and services, as gross value added. Revenue can be measured by sales, excludes value added tax, plus interest and dividend receipts,

\footnotetext{
${ }^{7}$ The ministry has collected the records of the entire inward monetary transactions that have been identified as a foreign direct investment since 1964, and published the data at international notification statistics center (INSC). The INSC foreign transaction data excludes equity investment, and the other capital and reinvested earnings.

${ }^{8}$ The database is available at http://www.kisvalue.com but it is not free to access and no English website is provided.
} 
and the production cost is compensation of employees plus purchases of intermediate good and services, changes in inventories, depreciation, and taxes that excludes value added tax. We take fixed asset and number of employees as the measures of physical capital and labor input respectively. Investment is the annual changes in fixed assets, which is the first order lagged difference of fixed asset. Note that all variables are in real terms, adjusted by two-digit industry classification level GDP deflators. We use Korean Standard Industry Classification (SIC) to match GDP deflators with SOE in our dataset. There are 65 industries in two-digit level SIC so that each industry's financial figures have been deflated by different GDP deflators.

\subsection{Characteristics of FDI in the Korean Corporates}

We first have a look at whether FDI in Korean SOEs have distinctive characteristics in terms of type, and country of origin. ${ }^{9}$ The data have a self-reported category of FDI type that consists of i) single incorporation, ii) joint incorporation, iii) right issues as a domestic business entity, and iv) right issues as a foreign business entity. The data also have a self-reported category of FDI purpose that consists of building i) factories, ii) sales establishments, iii) mergers and acquisitions (M\&A), and etc. The data have also the FDIs' country of origin as well.

Table 2. Descriptive Statistics of FDI Receiving by Firm Type

\begin{tabular}{lccccccc}
\hline \hline & \multicolumn{3}{c}{ Private corporates } & & \multicolumn{3}{c}{ State Owned Enterprises } \\
\cline { 2 - 4 } \cline { 6 - 7 } Type & Median Std.Dev & Total & & \multicolumn{3}{c}{ Median Std.Dev } & Total \\
\cline { 2 - 4 } Factory & 237 & 14,109 & $7,071,413$ & & 5,000 & 0.00 & 5,000 \\
Business & 33 & 8,959 & $21,865,034$ & 2,902 & 12,582 & 170,950 \\
M\&A & 580 & 65,765 & $5,334,220$ & 0.00 & 0.00 & 0.00 \\
Etc & 111 & 3,361 & 18,091 & 0.00 & 0.00 & 0.00 \\
\hline
\end{tabular}

FDI receiving amouts are recorded in thousand U.S. dollar. We convert the FDI receiving amount to the Won, Korean currency, and adjusted its price level change with respect to time using the Korean consumer price index (CPI), then we convert it back to U.S. dollar and adjusted its price level change using the U.S. CPI for urban consumers. So, the reported FDI receivings in the table are in real thousand U.S. dollar. Note that those currency conversions and price level adjustments are done by monthly statistics.

These FDI type and country of origin can be indicators that show whether a particular FDI is subject to a MNE's business operation, and if so, the productivity concerned empirical analysis would be biased. Theory of FDI in international business asserts that foreign investors make investment decisions in purpose of their business operation, rather than expect to make positive investment return from the invested domestic firm's own business operation. The purpose of FDI for MNEs' business operation includes: obtaining ownerships for domestic corporates, locating their production and sales facilities to internalize their business. This is known as the eclectic theory, or the theory of ownership, location, and internalization (OLI), proposed by Dunning $[12,13]$, and Trevino et al [27]. The OLI framework takes an important

\footnotetext{
${ }^{9} \mathrm{We}$ thank an anonymous referee for raising the issues that motivated us to write this section.
}

role in a firm level FDI analysis because the OLI can explains FDI's heterogeneous characteristics within country, as well as between country of origins. Obtaining ownership of domestic firms is demanded when the foreign investors make the vertical FDI, whereas the greenfield or horizontal FDI do not necessary to obtain the ownership. In the same way, some FDI aims to localize the investor MNEs' production facilities only, or sales facilities only, or both.

Since SOEs' ownership belong to the government and selling the ownership is restricted, however, the ownership concerned FDI is merely observed or insignificant in our data and empirical analysis. Table 2 reports descriptive statistics for total FDI receiving by corporate type and FDI purpose. The right panel of the table is for SOEs and M\&A purpose FDI are reported as zero, which means there are no $M \& A$ purpose FDI in the Korean SOEs, unlike the FDI in private corporates that have about 5 billion U.S. dollar in total, reported in the left panel. There is, moreover, only one case of factory building FDI for the SOEs with 5 million U.S. dollars in total, reported in the first row of the right panel, and the rest of FDI in SOEs are all for sales or other business establishments.

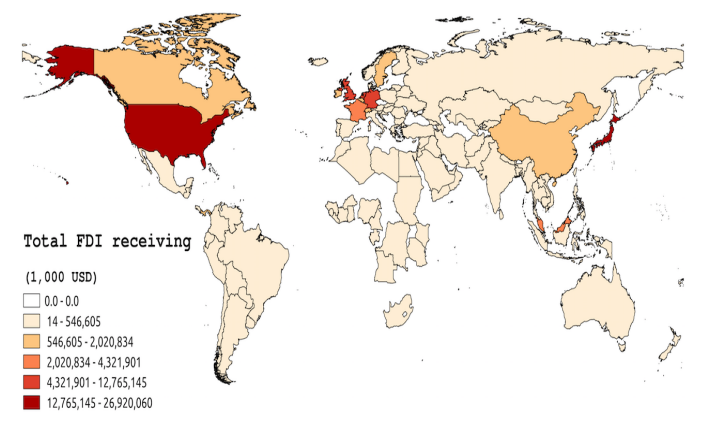

(a) FDI in Private Corporates

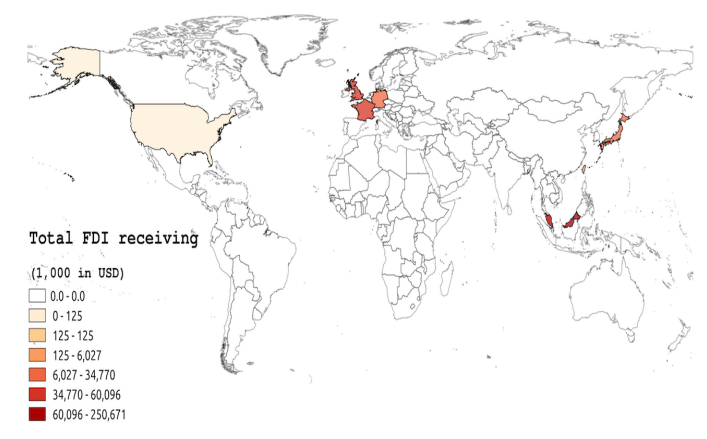

(b) FDI in State Owned Enterprises

Figure 3. FDI's Country of Origin

We further look at the FDI's country of origin in regards to the location advantage seeking or internalization of MNEs business purposes. There are other possible factors that can cause biased estimations in our empirical analysis, but there seems to be no significant variation over the FDI in SOEs' country of origins, unlike the FDI in private corporates. Figure 3 is maps for countries that have invested in Korean domestic corporates in FDI form. Panel (a) is the map for FDI in private corporates and there are 122 countries that have invested in the Korean private corporates. However, 
only eight countries have invested in Korean SOEs and they are mostly high income, democratic, and market economy oriented countries such as Germany, France, United States, United Kingdom, Japan, Taiwan, and etc. Moreover, the western European countries have invested about 50 million U.S. dollar each, while U.S. and Japan have invested in the Korean SOEs about 125 thousand and 15 million dollar respectively.

From Table 2 and Figure 3, we find that our empirical analysis would not be affected significantly by the OLI factors, institution, and resource based concerns, since we analyze FDI specifically in SOEs. FDI's country of origin can explain MNEs' institutional and locational advantage seeking investment, or internalization of their business. FDI in SOEs, however, have little concern about those factors by looking at Figure 2 and the investor countries' characteristics. The western European countries that have predominantly invested in the Korean SOEs share quite similar characteristics in terms of income, productivitity, and political institutions, even before the European Union (EU) has established.

\subsection{SOE and Market Competitiveness}

We then analyze market concentration indices to examine the validity of the critical assumptions for the model (4.2) that a SOE do not operate in perfect competitive environment but instead in a highly concentrated industry. We calculate Herfindahl-Hirschman Index (HHI) and the four-firm concentration ratio $\left(\mathrm{CR}_{4}\right)$ for each Korean industries in SIC using the Korean financial statement data that covers all public companies and statutory audit business entities that mandate to report their financial statements. We perform regression analyses of treatment dummy variables for industries with SOE, FDI recipients, and Privatized SOE, on the concentration indices. The regressions capture average treatment effects (ATE) of the industries with SOE, FDI recipients, and Privatized SOE and their interactions further capture differences-in-differences (DID) estimates of the ATE to examine differences in market concentration with respect to type of member firms in an industry.

Pooling the data for all years, we find that the market concentration in Korean industries is relatively small, and industries with SOE or privatized SOE have significantly higher concentration than the other industries. According to the Horizontal Merger Guidelines by U.S. Department of Justice and the Federal Trade Commission, "HHI below 1,500 are not concentrated, HHI between 1,500 and 2,500 are moderately concentrated, and HHI above 2,500 are highly concentrated market." We apply this rule to show the extent of market concentration. The last row in Table 3 reports average concentration indices if the industry has neither SOE nor FDI recipient firms. The overall average $\mathrm{HHI}$ in column 1 is 944 significantly lower than 1,500. The average HHI of SOE and privatized SOE, columns 1 and 4 respectively, are significantly positive, and this pattern is observed consistently in $\mathrm{CR}_{4}$.

The interaction effect of FDI with SOE and privatized SOE are negative, implying that industries with SOE or privatized SOE that have ever received FDI are more likely to be less concentrated than the other industries. In other words, the industries with SOE or privatized SOE that have ever received FDI are more likely to be competitive. The third and and the fifth rows in Table 3 report the interaction effects for SOE with FDI and privatized SOE with FDI respectively. Those effects are negatively significant on both $\mathrm{HHI}$ and $\mathrm{CR}_{4}$, reported in the first and fifth column respectively. Note that the interaction effects are DID estimates for each treatment group.

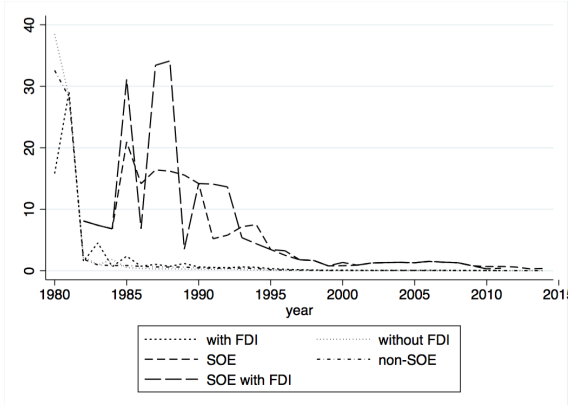

(a) 2-digit SIC

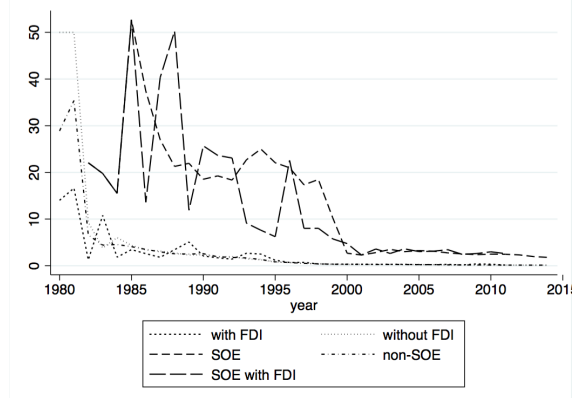

(b) 3-digit SIC

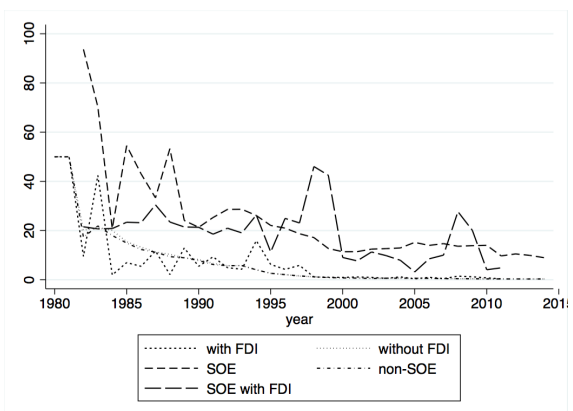

(c) 4-digit SIC

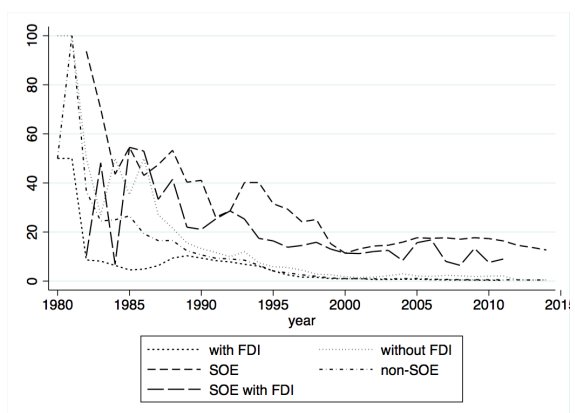

(d) 5-digit SIC

Figure 4. Median Industry Market Share by Firm Type 
Table 3. Average Treatment Effect Estimates for Market Concentration

\begin{tabular}{|c|c|c|c|c|c|c|c|c|}
\hline & \multicolumn{4}{|c|}{ Herfindahl-Hirschman Index } & \multicolumn{4}{|c|}{ The four-firm Concentration Ratio $\left(\mathrm{CR}_{4}\right)$} \\
\hline & All year & 1980-1989 & 1990-1999 & $2000-2011$ & All year & 1980-1989 & $1990-1999$ & $2000-2011$ \\
\hline \multirow[t]{2}{*}{ SOE } & $662.54 * * *$ & $1357.40 * * *$ & $817.81^{* * *}$ & -163.39 & $8.87^{* * * *}$ & $17.22 * * *$ & $12.18 * * *$ & -1.84 \\
\hline & [117.9] & [204.9] & {$[220.5]$} & [181.1] & {$[1.3]$} & [2.3] & [2.4] & {$[1.7]$} \\
\hline \multirow[t]{2}{*}{ FDI recipients } & $-334.25 * * *$ & $1116.83 * * *$ & -111.55 & $-1116.78^{* * *}$ & $4.91 * * *$ & $22.46 * * *$ & $12.87 * * *$ & $-8.16^{* * *}$ \\
\hline & {$[52.4]$} & [132.2] & {$[93.8]$} & {$[68.5]$} & {$[0.6]$} & [1.6] & [1.0] & [0.7] \\
\hline SOE with FDI & $-402.61 * *$ & -242.67 & -470.59 & 142.46 & $-4.75 * *$ & -1.38 & -0.74 & -1.82 \\
\hline (Interaction) & [190.3] & [494.1] & [315.7] & {$[266.7]$} & {$[2.0]$} & {$[5.0]$} & {$[3.2]$} & {$[2.4]$} \\
\hline \multirow[t]{2}{*}{ Privatized SOE } & 526.55 & & 377.79 & $1131.37 * * *$ & 0.57 & & $17.64 * * *$ & $7.47 * *$ \\
\hline & [324.9] & & [247.3] & [348.9] & [2.9] & & [2.7] & {$[3.0]$} \\
\hline Privatized SOE with FDI & $-2100.08^{* * *}$ & & -926.79 & $-2057.55^{* * *}$ & $-14.81 * * *$ & & $-16.92 * * *$ & $-8.12 *$ \\
\hline (Interaction) & [433.2] & & {$[920.8]$} & [471.7] & [4.1] & & {$[5.1]$} & {$[4.3]$} \\
\hline \multirow[t]{2}{*}{ Constant } & $944.45 * * *$ & $780.33^{* * *}$ & $3698.15^{* * *}$ & $4531.22 * * *$ & $10.69 * * *$ & $8.70 * * *$ & $50.87 * * *$ & $78.15 * * *$ \\
\hline & [101.6] & [100.3] & [149.2] & [127.8] & [1.2] & {$[1.2]$} & [1.7] & [1.3] \\
\hline $\begin{array}{l}\text { Year Fixed } \\
\text { (Dummies) }\end{array}$ & yes & yes & yes & yes & yes & yes & yes & yes \\
\hline R-squared & 0.041 & 0.072 & 0.003 & 0.027 & 0.178 & 0.125 & 0.044 & 0.095 \\
\hline \# of obs & 26964 & 7490 & 7490 & 11984 & 26964 & 7490 & 7490 & 11984 \\
\hline
\end{tabular}

Notes: Standard errors are reported in parentheses and Heteroskedasticity Robust Standard Errors are reported in square brackets. The symbols, *, **, and *** indicate respectively that the estimated coefficient is statistically significant under $10 \%, 5 \%$, and $1 \%$ significance levels.

The negative interaction effects, reported in $3^{\text {rd }}$ and $5^{\text {th }}$ rows, can be interpreted as which industries with SOE and privatized SOE become competitive or the SOE exercises monopoly pricing where lowering quantity supplied to the point that maximizes its profit, if they have ever received FDI. Both cases can have smaller market share and therefore, the concentration indices are smaller than those for the other industries but it is not clear in what way FDI plays a role on the effect of market concentration and competitiveness. FDI's own effects are significantly negative on HHI but those are positive on $\mathrm{CR}_{4}$ in the second row of the first and fifth columns in Table 3 .

The average market concentration indices have been changed drastically when we disaggregate the data by decode. The second, third, and fourth columns are the estimates for 80 s, 90 s, and 2000s respectively, and those show that the HHI has made stiff increase over the decades. This pattern is consistent with $\mathrm{CR}_{4}$ in the sixth, seventh, and eighth columns in Table 3. This market concentration trend is consistent with Korean economic growth dynamics with extremely fast rates in the 80s and early 90s, then a steep decline during the harsh recession in 1997 and the accompanying bankruptcies. ${ }^{10}$ Draconian financial reform policies were then implemented afterward. About 4,000 $\mathrm{HHI}$ and $70 \% \mathrm{CR}_{4}$ in Table 3 are almost suspiciously high but those can be understood as a reflection of the Korean economic dynamics, or those might be amplified because we use the most detailed industry classification.

SOEs' market share and its ranking are greater than the other companies regardless of time and industry classifications. Figure 4 presents time plots for median industry market shares by firm type and different industry classification. Note that two, three, four, and five-digit SIC have 76, 228,

\footnotetext{
${ }^{10}$ Lim and Halm [18] provide that in Korea, 14 out of 30 largest companies reported in 1996 went bankrupt until 1999. See Lim and Halm [18] for more detail statistics.
}

487, and 1,145 industries respectively in the 2007 Korean SIC. As shown in Figure 4, more detail SIC have lower median industry market share but SOE and SOE with FDI tend to have greater market shares than the other firms and industries in any time.

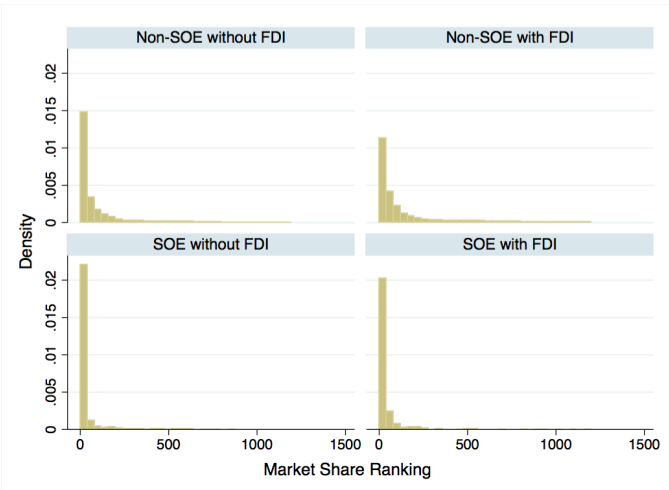

Figure 5. Market Share Ranking within Industry

Moreover, the SOE and SOE with FDI tend to have greater market share rankings within their industries. Figure 5 presents histograms of market share rankings by firm type. The lower two panels in Figure 5 seem to have ranking distributions more left skewed that is closed to the top rank, than the top two panels. This is additional indirect evidence that SOE are likely to operate in concentrated markets and industries.

\subsection{Descriptive Statistics for SOE with FDI recipients and non-recipients}

The top panel of Table 4 reports the descriptive statistics for variables in the model (4.2) of Korean SOE by categorizing the SOE by positive or zero FDI receipt. The left panel on the top is for SOE, which have never received FDI, and 
the right panel is for SOE that have received FDI at least once, over the sample periods, from 1980 to 2011. As we can see the mark-up at the first row, SOE with FDI have higher means and significantly lower standard deviations than SOE without FDI. This implies that FDI flows into the SOE with higher and stable returns, and may result from significantly lower average total cost of the SOE with FDI. By looking at the standard deviation of the average total cost for SOE without FDI, however, we cannot conclude, in a naïve way, that SOE with FDI have better quality production technology. The production technology then enable them to produce goods and services with lower production costs, and eventually they earn higher profit than SOE without FDI, under the same revenue stream. The volatile average total cost of SOE without FDI makes difficult to conclude that the higher mark-up of SOE with FDI comes from less marginal cost at a given price level.

By looking at the differences of the other variables in the table, which are related to production technology such as output and its factor inputs, capital and labor, we can see that the statistics show no variables have significant difference between SOE with and without FDI. These findings are consistent with graphical representations of the distributions of such variables. Figure 6 is the non-parametric distribution estimations for the four production related variables. As we interpreted in the top panel of Table 3, no variables have distributions that take significantly different places on their intervals.

The lower panel of Table 3 shows descriptive statistics for the variables, categorized by privatization. The left panel is for SOE that are not privatized, or before their privatization, and the right panel is for privatized SOE. The privatized SOE have negative mark-up, whereas non-privatized SOE still earn positive mark-up. This pattern looks the same as the pattern in the top panel of the table in which higher average total cost of privatized SOE yields negative mark-up, even though the privatized SOE have slightly higher average total revenue. But this is statistically inconclusive because the standard deviation of privatized SOE's average total cost is incomparably greater than non-privatized SOE's.

The panel (a) of Figure 7 shows an empirical average total revenue function of Korean SOE, which is horizontal over the associated output level. The solid line through the data points is the LOESS (locally weighted scatterplot smoothing) line, a non-parametric method to fit a simple regression line, which shows the mean relationship between average total revenue and output of Korean SOE, confirming that it is horizontal. This figure provides indirect evidence that SOE operate under the particular pricing. The SOE operate obviously in monopoly industries so that their average total revenue curve is downward sloping so that they have downward sloping demand as well, which allows them to exercise monopoly pricing to maximize their profit. There might be an external force, however, to keep the average total revenue curve horizontal, and that force is the public pricing in which we can assume Korean government's pricing impulses on SOE.

Unlike the empirical average total revenue curve, the average total cost curve, in panel (b) of Figure 7, seems to take a U-shape, consistent with the theory of firms that average total cost function is a convex function of output so that it yields upward sloping marginal cost. Note that the solid line in the panel (b) is the LOESS non-parametric average cost curve. The two firms' production decision related plots provide notable evidence support its assumptions of our theoretical model. The model estimation is thus relevant way to investigate specific preferences of foreign investors in SOE on SOE in a novel way that compared to previous studies of FDI determinants.

Table 4. Descriptive Statistics for SOE with and without FDI

\begin{tabular}{|c|c|c|c|c|c|c|c|c|c|c|}
\hline & \multicolumn{5}{|c|}{ Without FDI } & \multicolumn{5}{|c|}{ With FDI } \\
\hline & \# of obs & Mean & Std. dev & Min & Max & \# of obs & Mean & Std. dev & Min & Max \\
\hline Mark-up & 1234 & 0.204 & 25.661 & -900.411 & 6.547 & 67 & 0.821 & 0.591 & -3.761 & 1.014 \\
\hline (Average) Total Revenue & 1259 & 1.244 & 7.080 & 0.475 & 252.085 & 80 & 1.035 & 0.085 & 1 & 1.600 \\
\hline (Average) Total Cost & 1234 & 1.044 & 32.806 & 0.002 & 1152.496 & 67 & 0.207 & 0.661 & 0.007 & 5.361 \\
\hline Output & 1259 & 25.921 & 0.206 & 14.881 & 31.578 & 80 & 26.327 & 2.114 & 19.615 & 30.707 \\
\hline Capital & 1332 & 25.168 & 2.700 & 14.845 & 32.111 & 91 & 26.547 & 2.192 & 19.132 & 30.631 \\
\hline Labor & 1289 & 6.294 & 1.904 & 0 & 11.017 & 77 & 5.960 & 2.231 & 1.099 & 10.367 \\
\hline Investment & 1237 & 0.169 & 0.584 & -8.309 & 9.937 & 87 & 0.161 & 0.622 & -1.121 & 3.873 \\
\hline \multirow[t]{3}{*}{ FDI } & 3299 & NA & NA & NA & NA & 93 & 30.349 & 3.149 & 15.175 & 32.975 \\
\hline & \multicolumn{5}{|c|}{ Non-privatized } & \multicolumn{5}{|c|}{ Privatized } \\
\hline & $\#$ of obs & Mean & Std. dev & Min & Max & $\#$ of obs & Mean & Std. dev & Min & Max \\
\hline Mark-up & 834 & 0.939 & 0.314 & -3.338 & 6.547 & 467 & -1.020 & 41.71 & -900.411 & 1.105 \\
\hline (Average) Total Revenue & 849 & 1.057 & 0.317 & 1 & 8.900 & 490 & 1.535 & 11.342 & 0.475 & 252.085 \\
\hline (Average) Total Cost & 834 & 0.117 & 0.267 & 0.002 & 4.377 & 467 & 2.580 & 53.328 & 0.004 & 1152.496 \\
\hline Output & 849 & 25.978 & 2.155 & 17.701 & 31.578 & 490 & 25.889 & 2.281 & 14.881 & 31.128 \\
\hline Capital & 909 & 25.305 & 2.814 & 14.845 & 32.111 & 514 & 25.172 & 2.460 & 14.914 & 31.290 \\
\hline Labor & 871 & 6.573 & 1.810 & 1.099 & 11.017 & 495 & 5.753 & 2.010 & 0 & 10.684 \\
\hline Investment & 834 & 0.200 & 0.482 & -4.523 & 3.873 & 490 & 0.117 & 0.727 & -8.309 & 9.937 \\
\hline FDI & 2655 & 0.090 & 1.645 & 0 & 32.000 & 737 & 3.504 & 9.774 & 0 & 32.975 \\
\hline
\end{tabular}

Notes: Average total revenue is total revenue, divided by output, and average total cost is also total cost, divided by output. Mark-up is calculated by subtracting average total cost from average total revenue."\# of obs" and "Std. dev" are the acronyms of "number of observations" and "standard deviation" respectively. Output, capital, labor, investment, and FDI are natural logarithmic scales. "Non-privatized " sample includes never privatized and before privatized SOE. 


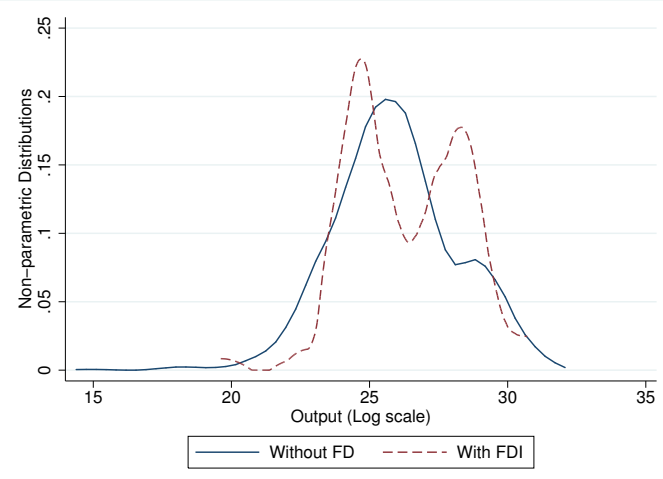

(a) Output

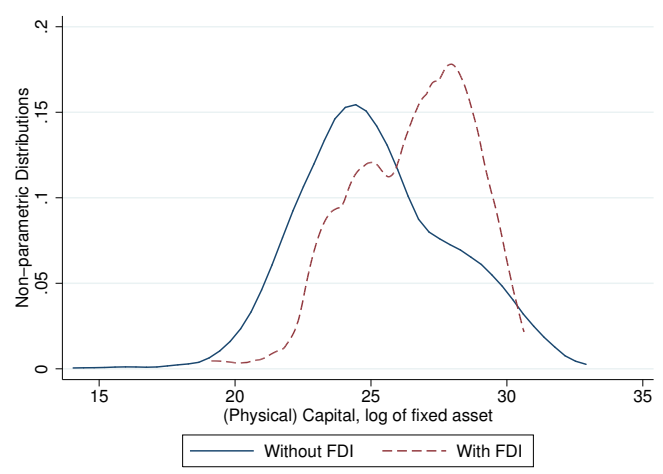

(c) Capital Input

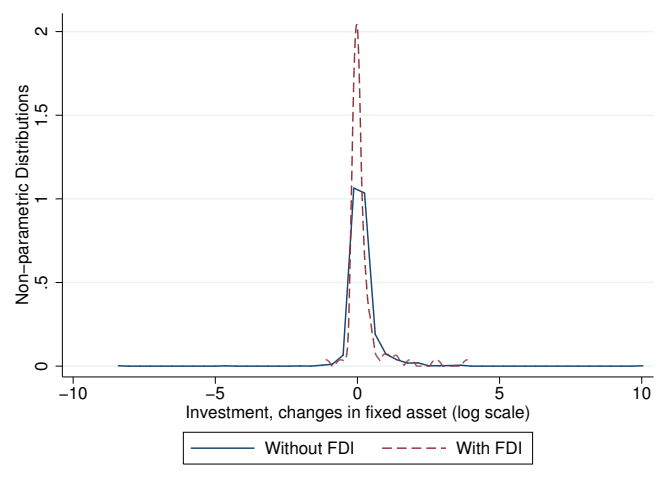

(b) Investment

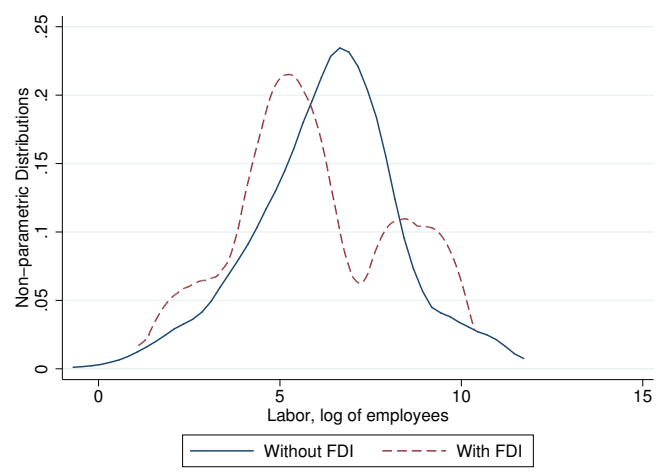

(d) Labor Input

Figure 6. Empirical Distributions of Production Related Variables

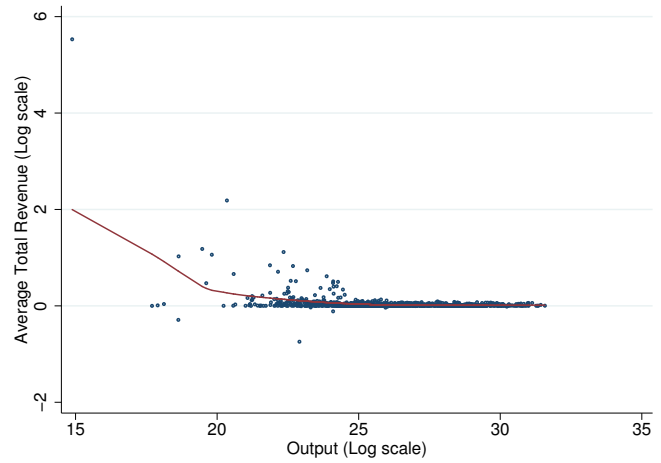

(a) Average Total Revenue

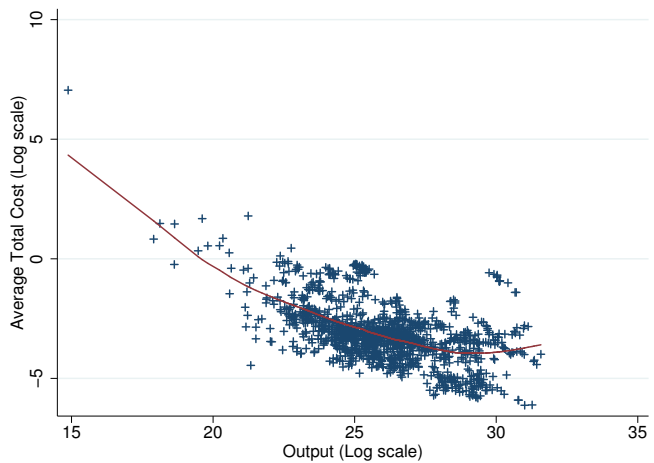

(b) Average Total Cost

Figure 7. Empirical SOE’s Production

\subsection{Estimation}

We aggregate FDI amount in the data by firm and by year to match the variables from the annual corporate income statements. We use each firms' accumulated FDI to treat it as a stock variable rather than a flow. Thus we have an annual panel dataset for Korean SOES with inward FDI records. The model that represents the panel data is given as:

$$
\begin{aligned}
I_{i t} & =\beta_{0}+\beta_{1} \cdot\left(A T R_{i t-1}-A T C_{i t-1}\right)+\beta_{2} y_{i t} \\
& +\beta_{3} k_{i t}+\beta_{4} l_{i t}+\beta_{5} \cdot I_{i t}^{\prime}+u_{i t},
\end{aligned}
$$

where $u_{i t}$ is an idiosyncratic error term. We can use the model parameters to hypothesize the effect of the explanatory variables on FDI decisions. For instance, if $\beta_{2}$ and $\beta_{4}$ are significantly positive whereas $\beta_{1}$ is statistically insignificant, it means FDI aim to realize investment return from competitive profit by increasing capital inputs and employment. This can be an evidence for FDI spillover effect. On the other hand, if $\beta_{1}$ is significantly positive while $\beta_{2}$ and $\beta_{4}$ are negative, it means FDI for SOE aim to realize monopoly profit by reducing output level below the socially optimal level until monopoly profit is maximized. This implies inward FDI 
to SOE does not play a role in increasing SOEs's productivity, as has been widely argued in the previous literature on inward FDI. In this case, foreign investors are motivated by capturing sum of the monopoly profit.

In order to estimate the model consistently, we use three different estimation methods, which are ordinary least squares (OLS), panel data model, and censored tobit. Since the model is derived from the theory that we reviewed in the section 4, OLS with time and cross section dummies with consistent estimation despite the presence of uncontrolled cross sectional heterogeneity. Panel data model estimation, called random effect and fixed effect, yields consistent estimation when there exists the uncontrolled heterogeneity. The possible source of bias in FDI determination model estimation is data censoring problem. Because FDI purchases either physical capital or firms' stock, it is obvious that the investor is able to sell it. In this case, FDI takes negative values, but the FDI data record only the positive amounts of FDI will the negative amounts are censored.

The data censoring is a well known source of bias in econometrics, and the censored tobit model is known as an econometric method that controls for the bias. To illustrate inconsistent estimation problem in FDI model, here we consider a vector representation of the model (5.1) as:

$$
I_{i t}^{*}=\mathbf{x}_{i t} \boldsymbol{\beta}+u_{i t}, \quad u_{i t} \mid \mathbf{x}_{i t} \sim N\left(0, \sigma^{2}\right),
$$

where $I_{i t}^{*}$ is latent FDI investment that takes value from negative to positive interval. Let $I_{i t}$ be an observable FDI record that takes value only from positive interval so that $I_{i t}=\max \left(0, I_{i t}^{*}\right)$. If we deal with the observable FDI, then the population model that we want to estimate is following:

$$
\begin{aligned}
E\left[I_{i t} \mid \mathbf{x}_{i t}, I_{i t}>0\right] & =\mathbf{x}_{i t} \boldsymbol{\beta}+E\left[u_{i t} \mid u_{i t}>-\mathbf{x}_{i t} \boldsymbol{\beta}\right] \\
& =\mathbf{x}_{i t} \boldsymbol{\beta}+\sigma\left[\frac{\phi\left(\mathbf{x}_{i t} \boldsymbol{\beta} / \sigma\right)}{\Phi\left(\mathbf{x}_{i t} \boldsymbol{\beta} / \sigma\right)}\right]
\end{aligned}
$$

where $\phi(\cdot)$ and $\Phi(\cdot)$ are normal probability distribution and cumulative distribution functions respectively. The far right term is the inverse mills ratio and it plays a role as an omitted variable so any estimators without controlling the inverse mills ratio yields inconsistency if the data is left censored and any independent variables are correlated with the inverse mills ratio.

\subsection{Result}

Table 5 reports the FDI model estimates using the three different methods. The last two columns report censored tobit regression results, and the last row of the two columns show that inverse mills ratio is highly significant. This implies the OLS and panel estimates are biased due to the left censored dependent variable. As we can see in the first row, mark ups, defined by subtracting average total cost from average total revenue, are negative in both OLS and Panel data model while the censored tobit estimate is positive. Negative mark up means that FDI leads SOE to sacrifice their monopoly profit to produce more and it is the case where social welfare is improved by FDI.
Censored tobit estimates show that, however, the positive role of FDI is exaggerated by data censoring bias. In the second and fourth rows, output and labor input, we can see the same pattern of difference between censored tobit and the other estimations. In OLS and panel data model, output and labor input are positive but statistically insignificant for all model specifications, which means the firms try to realize monopoly profit by reducing output and labor input when they receive FDI, and positive mark-up decreases FDI but it is statistically insignificant. The OLS and panel data model estimates can be interpreted that foreign investors, who are willing to invest in SOE, prefer the SOE with positive profit.

The output and capital input are positive in the fifth and sixth column, which come up with positive and significant coefficients of mark-up, whereas coefficients of labor input are negative in both estimates. The only difference between two model, estimated by censored tobit, is whether it controls for industry or group company by dummy variables. Because data matrix becomes singular once the both firms and group dummies are considered at the same time, we could not try to estimate the model with both group and industry dummies to obtain group and industry fixed effect estimation. Thus, interpreting only the coefficients that have same sign in both censored tobit model is relevant. Even though we can only interpret mark up and privatization that have same signs, however, the consequences that FDI flows into SOE to earn monopoly profit as its return does not change because those two censored tobit estimations are consistent with each other. Privatized SOE is clearly good chance to exercise monopoly pricing for both domestic and foreign investors.

Overall, the several different estimates of FDI on SOE shows that 1) foreign investors consider the mark-up profit of SOE, caused by the government pricing strategy so that it is stable and less risky, 2) foreign investors also consider production technology of the SOE but only for capital intensive production technology, not labor intensive, and 3) privatized SOE are highly preferable for foreign investors. These three results give a new perspective on the positive effect of FDI on domestic firms and business that contrasts with the previous literature on FDI effects. Because the foreign investors prefer firms with capital intensive production technology (positive coefficient of capital input) a small number of employees (negative coefficient of labor input), and give the highest priority to privatization of SOE (largest coefficient values of privatization). These three results are the strong evidence that the foreign investors make FDI decision on the SOE in which the higher and stable profit is guaranteed, so that increasing firms' productivity and competing with the other firms that operate in the same industry are not necessary conditions for investment.

It is possible that the foreign investors care about investing SOEs' productivity as much as about the stable and risk-less investment return they will earn. But because of the ROI fixed pricing, the SOE have no incentive to increase their productivity by devoting more time and money. Even for the privatized SOE, furthermore, increasing productivity and competing with the other firms are not attractive. The positive coefficient of capital inputs show that the greater than the 
Table 5. Model Estimates of Foreign Direct Investment

\begin{tabular}{|c|c|c|c|c|c|c|}
\hline & \multicolumn{2}{|c|}{ Fixed Effect OLS } & \multicolumn{2}{|c|}{ Panel Data Model } & \multicolumn{2}{|c|}{ Censored Tobit } \\
\hline & (1) & (2) & Random Effec & Fixed Effect & $(5)$ & (6) \\
\hline Mark-up & $-0.0077 *$ & $-0.0077 *$ & -0.0043 & -0.0077 & $1.1253 * * *$ & $1.1211 * * *$ \\
\hline (A year lagged) & {$[0.003]$} & {$[0.003]$} & [0.004] & {$[0.005]$} & {$[0.283]$} & {$[0.286]$} \\
\hline \multirow[t]{2}{*}{ Output } & 0.3310 & 0.3310 & 0.3702 & 0.3310 & $1.0900 * * *$ & $1.0741 * * *$ \\
\hline & {$[0.187]$} & {$[0.187]$} & {$[0.271]$} & {$[0.283]$} & {$[0.024]$} & {$[0.023]$} \\
\hline \multirow[t]{2}{*}{ Capital } & $-0.3435 *$ & $-0.3435^{*}$ & -0.0883 & -0.3435 & $1.637 * * *$ & $1.6117 * * *$ \\
\hline & {$[0.168]$} & {$[0.168]$} & {$[0.200]$} & {$[0.243]$} & {$[0.023]$} & {$[0.023]$} \\
\hline \multirow[t]{2}{*}{ Labor } & $1.0943^{* *}$ & $1.0943 * *$ & 0.4724 & 1.0943 & $-0.8940 * * *$ & $-0.8646^{* * *}$ \\
\hline & {$[0.410]$} & {$[0.410]$} & {$[0.676]$} & {$[0.961]$} & [0.093] & [0.091] \\
\hline \multirow[t]{2}{*}{ Investment } & -0.4567 & -0.4567 & -0.4629 & -0.4567 & $2.711 * * *$ & $2.7202 * * *$ \\
\hline & [0.335] & {$[0.335]$} & {$[0.477]$} & {$[0.502]$} & {$[0.495]$} & [0.509] \\
\hline \multirow[t]{2}{*}{ Privatization } & $2.2082 * * * 2$ & $2.2082 * * *$ & $2.1602 *$ & $2.2082 *$ & $14.714 * * *$ & $14.7164 * * *$ \\
\hline & {$[0.548]$} & {$[0.548]$} & {$[1.067]$} & {$[1.086]$} & {$[0.574]$} & {$[0.572]$} \\
\hline Year Fixed & yes & yes & yes & yes & yes & yes \\
\hline \multicolumn{7}{|l|}{ (Dummies) } \\
\hline \multicolumn{7}{|l|}{ (Dummies) } \\
\hline Firm Fixed & no & yes & no & no & yes & yes \\
\hline \multicolumn{7}{|l|}{ (Dummies) } \\
\hline Group Company Fixed & no & yes & yes & no & yes & no \\
\hline \multicolumn{7}{|l|}{ (Dummies) } \\
\hline \multirow[t]{2}{*}{ Constant } & -5.3671 & -6.5245 & -8.5709 & -5.4865 & $-111.2257 * * *$ & $-113.1220 * * *$ \\
\hline & [4.636] & [4.591] & [6.383] & [7.995] & {$[0.628]$} & {$[0.626]$} \\
\hline \multirow[t]{2}{*}{ Inverse Mill's ratio } & & & & & $7.0285^{* * *}$ & $7.0282 * * *$ \\
\hline & & & & & {$[0.078]$} & {$[0.072]$} \\
\hline$R^{2}$ & 0.8092 & 0.8092 & 0.4609 & 0.0041 & $\{0.5678\}$ & $\{0.5678\}$ \\
\hline Number of Observations & 1176 & 1176 & 1176 & 1176 & 1176 & 1176 \\
\hline
\end{tabular}

firm's capital asset, the more FDI it attracts. It implies also that the industry in which the SOE operates is dominated by economies of scale so the SOE easily turns out to be a natural monopoly. In this situation, the SOE might possess already monopoly power and will exercise monopoly pricing immediately after being privatized. It is therefore a relevant guess that the foreign investors have a incentive to reduce output level that increases the privatized SOE's profit, since the reduction of output level from competitive level of output is the way of increasing profit by monopoly pricing.

In order to examine the inference that inward FDI on SOE does not affect firms' productivity and performance, we perform the model estimations with two different measures of firm performance as dependent variables and the lagged cumulative FDI receipts as independent variables. The two measures of firm performance are the return on invested capital (ROIC) and the return on asset (ROA), defined as the proportion of sum of net sales plus interest payments and the net sales itself respectively, out of total assets. ${ }^{11}$ Table 5 report

\footnotetext{
${ }^{11}$ Under the notion of the rate of return regulated pricing that prices of goods and services, produced by SOE, are regulated by government and it keeps the firms' rate of return, the model specification is irrelevant because the dependent variables, measures of rate of return, are exogenously given.
}

the estimates with different lagged FDI variables to investigate both short-run and long-run effect of FDI on firms' performance. As we can see in the first three rows in all columns, no model estimates and lagged FDIs are statistically significant. The other interesting fact that SOEs with high output levels and lower capital inputs perform better, and the effect of mark-up profit is significant but slightly smaller than the effect of output consistent with the results in table 4 .

These findings are consistent with the basic principle of operating SOE and the investment in physical capital. The primary goal of SOEs' market operation is to produce goods and services sufficiently at a lower price, and supply to their economy as a whole to make it better off. This goal, called socially optimum, can be achieved regardless of the amount of FDI the SOE has received, and the government would be willing to allow earning higher rate of return to the investors. The trade off between the higher rate of return, given by government, and cost to produce more goods and services at a lower price may occur in foreign investors' decision. If any SOE have fixed the rate of return, foreign investors will search the optimal investment opportunity that yields the

Here, we use the model as a pilot and supplement empirical analysis to compare the result with previous literature on FDI. 
Table 6. Model Estimates of Firm performances

\begin{tabular}{|c|c|c|c|c|c|c|c|c|}
\hline & \multicolumn{2}{|c|}{ A year lag } & \multicolumn{2}{|c|}{ Two years lag } & \multicolumn{2}{|c|}{ Three years lag } & \multicolumn{2}{|c|}{ All three years lag } \\
\hline & ROIC & ROA & ROIC & ROA & ROIC & ROA & ROIC & ROA \\
\hline Lagged FDI & 0.0006 & 0.0075 & & & & & 0.0003 & 0.0057 \\
\hline (1 year) & {$[0.003]$} & {$[0.005]$} & & & & & {$[0.003]$} & {$[0.004]$} \\
\hline Lagged FDI & & & 0.0006 & 0.0067 & & & -0.0006 & -0.0022 \\
\hline (2 years) & & & {$[0.002]$} & {$[0.005]$} & & & {$[0.003]$} & {$[0.004]$} \\
\hline Lagged FDI & & & & & 0.0008 & 0.0068 & 0.0011 & 0.0050 \\
\hline (3 years) & & & & & {$[0.002]$} & {$[0.004]$} & {$[0.003]$} & {$[0.003]$} \\
\hline Mark up & $\begin{array}{c}0.0063 * * * \\
{[0.001]}\end{array}$ & $\begin{array}{c}0.0053 * * * \\
{[0.001]}\end{array}$ & $\begin{array}{c}0.0063 * * * \\
{[0.001]}\end{array}$ & $\begin{array}{c}0.0053 * * * \\
{[0.001]}\end{array}$ & $\begin{array}{c}0.0063 * * * \\
{[0.001]}\end{array}$ & $\begin{array}{c}0.0053^{* * * *} \\
{[0.001]}\end{array}$ & $\begin{array}{c}0.0063 * * * \\
{[0.001]}\end{array}$ & $\begin{array}{c}0.0053 * * * \\
{[0.001]}\end{array}$ \\
\hline Output & $\begin{array}{c}0.7200 * * * \\
{[0.066]}\end{array}$ & $\begin{array}{c}0.8367 * * * \\
{[0.074]}\end{array}$ & $\begin{array}{c}0.7200 * * * \\
{[0.066]}\end{array}$ & $\begin{array}{c}0.8367 * * * \\
{[0.074]}\end{array}$ & $\begin{array}{c}0.7198 * * * \\
{[0.066]}\end{array}$ & $\begin{array}{c}0.8362 * * * \\
{[0.074]}\end{array}$ & $\begin{array}{c}0.7198 * * * \\
{[0.066]}\end{array}$ & $\begin{array}{c}0.8356 * * * \\
{[0.074]}\end{array}$ \\
\hline Capital & $\begin{array}{c}-0.7622 * * * \\
{[0.058]}\end{array}$ & $\begin{array}{c}-0.9225^{* * *} * \\
{[0.056]}\end{array}$ & $\begin{array}{c}-0.7621 * * * \\
{[0.058]}\end{array}$ & $\begin{array}{c}-0.9227 * * * \\
{[0.056]}\end{array}$ & $\begin{array}{c}-0.7620 * * * \\
{[0.058]}\end{array}$ & $\begin{array}{c}-0.9215 * * * \\
{[0.056]}\end{array}$ & $\begin{array}{c}-0.7619 * * * \\
{[0.058]}\end{array}$ & $\begin{array}{c}-0.9213 * * * \\
{[0.056]}\end{array}$ \\
\hline Labor & $\begin{array}{l}-0.0670 \\
{[0.091]}\end{array}$ & $\begin{array}{l}-0.0245 \\
{[0.077]}\end{array}$ & $\begin{array}{r}-0.0669 \\
{[0.091]}\end{array}$ & $\begin{array}{l}-0.0219 \\
{[0.077]}\end{array}$ & $\begin{array}{l}-0.0670 \\
{[0.091]}\end{array}$ & $\begin{array}{l}-0.0223 \\
{[0.077]}\end{array}$ & $\begin{array}{l}-0.0671 \\
{[0.091]}\end{array}$ & $\begin{array}{l}-0.0247 \\
{[0.077]}\end{array}$ \\
\hline Investment & $\begin{array}{c}0.0076 \\
{[0.104]}\end{array}$ & $\begin{array}{l}0.0013 \\
{[0.094]}\end{array}$ & $\begin{array}{l}0.0078 \\
{[0.104]}\end{array}$ & $\begin{array}{l}0.0029 \\
{[0.094]}\end{array}$ & $\begin{array}{l}0.0080 \\
{[0.104]}\end{array}$ & $\begin{array}{c}0.0045 \\
{[0.095]}\end{array}$ & $\begin{array}{l}0.0078 \\
{[0.104]}\end{array}$ & $\begin{array}{l}0.0037 \\
{[0.095]}\end{array}$ \\
\hline Privatization & $\begin{array}{l}0.0836 \\
{[0.067]}\end{array}$ & $\begin{array}{l}0.1029 \\
{[0.060]}\end{array}$ & $\begin{array}{l}0.0840 \\
{[0.066]}\end{array}$ & $\begin{array}{l}0.1075 \\
{[0.060]}\end{array}$ & $\begin{array}{l}0.0838 \\
{[0.066]}\end{array}$ & $\begin{array}{l}0.1086 \\
{[0.060]}\end{array}$ & $\begin{array}{l}0.0838 \\
{[0.067]}\end{array}$ & $\begin{array}{l}0.1036 \\
{[0.060]}\end{array}$ \\
\hline $\begin{array}{l}\text { Year Fixed } \\
\text { (Dummies) }\end{array}$ & yes & yes & yes & yes & yes & yes & yes & yes \\
\hline $\begin{array}{l}\text { Industry Fixed } \\
\text { (Dummies) }\end{array}$ & yes & yes & yes & yes & yes & yes & yes & yes \\
\hline $\begin{array}{l}\text { Firm Fixed } \\
\text { (Dummies) }\end{array}$ & yes & yes & yes & yes & yes & yes & yes & yes \\
\hline $\begin{array}{l}\text { Group Company Fixed } \\
\text { (Dummies) }\end{array}$ & yes & yes & yes & yes & yes & yes & yes & yes \\
\hline Constant & $\begin{array}{l}3.1610 \\
{[1.728]}\end{array}$ & $\begin{array}{l}3.3751 \\
{[1.748]}\end{array}$ & $\begin{array}{l}3.1605 \\
{[1.726]}\end{array}$ & $\begin{array}{l}3.3650 \\
{[1.747]}\end{array}$ & $\begin{array}{l}3.1621 \\
{[1.724]}\end{array}$ & $\begin{array}{l}3.3543 \\
{[1.745]}\end{array}$ & $\begin{array}{l}3.1616 \\
{[1.730]}\end{array}$ & $\begin{array}{l}3.3771 \\
{[1.750]}\end{array}$ \\
\hline$R^{2}$ & 0.8956 & 0.9130 & 0.8956 & 0.9130 & 0.8956 & 0.9130 & 0.8956 & 0.9131 \\
\hline Number of Observations & 979 & 1175 & 979 & 1175 & 979 & 1175 & 979 & 1175 \\
\hline
\end{tabular}

highest profit, given by subtracting the marginal cost from the fixed rate of return. The very clear fact is that FDI on SOE does not necessarily increase productivity and market performance to earn higher return with respect to the amount of investment.

\section{Conclusion}

Throughout this study, we examine the potential dark side of the FDI, that foreign investors would only be interested in realizing positive excess return from domestic firm's markup, where positive profit is made by exercising monopoly pricing, and that foreign investors do not have an incentive to improve domestic firms' productivity. The consequence of this scenario is then no productivity spillover effect can be generated by FDI. From the econometric estimations of the FDI determination model (4.2) using Korean SOE data and FDI recipient records, we find that FDI is more likely to flow into a firm with large-scale physical capital and output, and positive mark-up, and the effect is the inverse of the number of workers in the firm.

As Wang and Wang [30] mentioned in conclusion, many developing countries have implemented FDI stimulus policies that provide tax benefit, government subsidies, and the other incentives to their foreign investors. The industry and the domestic economy overall might benefits from FDI, and the FDI literature has thoroughly examined this aggregate effect. In order to avoid misguided policy implementation in the developing countries by the FDI literature, the future research needs to pay attention to the finding that FDI may have the opposite effect on the domestic industries and economy in a specific situation.

We would like to offer an example of one of the largest Korean vehicle manufacturers, which shows that the FDI's productivity improvement may be illusory, for future research and policy designs on FDI. In 2004, a 51\% stake of Ssangyong Motor, 50 years old and the third largest Korean vehicle manufacturer, was sold to Shanghai Automotive Industry Corporation (SAIC), a Chinese SOE, after 5 years of government bailout program. In 2009, SAIC decided to sell its ownership for Ssangyong after filing a bankruptcy protection request to the Korean government, and a restructuring plan that includes 2,646 workers' layoff was announced. The Ssangyong's labor union went on strike and seized its main factory for two months. The police authority then intervened with the raids to evict the workers that caused aggressive fights, and finally the restructuring brought 1,666 workers to resign voluntarily and another 980 to be laid off. 


\section{Acknowledgements}

We thank Damir Cosic, Gabriel Movesyan, and all other CUNY Graduate Center's Economics student seminar participants for their helpful comments. We also thank Seokyoon Hwang, Kristin Mammen, Warrick Bell, and Gregory Pashayan for his great research assist. This research is also supported, in part, under National Science Foundation Grants CNS-0958379 and CNS-0855217, the City University of New York High Performance Computing Center at the College of Staten Island. This research was supported in part by the Sookmyung Women's University Research Grants in 2012.

\section{REFERENCES}

[1] Aitken, B.J. and Harrison, A.E., "Do domestic firms benefit from direct foreign investment? Evidence from Venezuela" American Economic Review, 89(3), 605-618, (1999).

[2] Bergstrand, J. H., and Egger, P. (2007)., "A knowledge-andphysical-capital model of international trade flows, foreign direct investment, and multinational enterprises" Journal of International Economics, 73(2), 278-308.

[3] Blonigen, B. A. (2005). "A review of the empirical literature on FDI determinants" Atlantic Economic Journal', 33(4), 383-403.

[4] Blonigen, B. A., and Piger, J. (2014). "Determinants of foreign direct investment" Canadian Journal of Economics, 47(3), 775-812.

[5] Bös , D., (1985). "Public sector pricing" Handbook of Public Economics, Ch 3, Vol 1, 129-211.

[6] Caballero, Ricardo J., (1991). "On the Sign of the InvestmentUncertainty Relationship," American Economic Review, 81, 279-288.

[7] Carr, D. L., Markusen, J. R., and Maskus, K. E. (2001). "Estimating the knowledge-capital model of the multinational enterprise" American Economic Review, 91(3), 693-708.

[8] Choe Sang-hun., "South Korean Police Try Again to Evict Workers From Auto Factory" New York Times 6 August 2009.

[9] Choe, S and Wassenerjan, B., "Korean Carmaker Seeks Receivership." New York Times 9 January 2009.

[10] Cho, Y. W, Sul, and Seo, M., (2008). "Foreign investors' block acquisition, purpose of acquisition and firm value," Journal of Korea Trade, 12, 67-105.

[11] Dixit, A, and Pindyck, R.S, (1994). Investment under Uncertainty. Princeton University Press, Princeton, NJ.

[12] Dunning, J. H. (1973). The determinants of international production. Oxford economic papers, 25(3), 289-336.

[13] Dunning, J. H. (2001). The eclectic (OLI) paradigm of international production: past, present and future. International journal of the economics of business, 8(2), 173-190.
[14] Eicher, T. S., Helfman, L., and Lenkoski, A. (2012). "Robust FDI determinants: Bayesian model averaging in the presence of selection bias" Journal of Macroeconomics, 34(3), 637651 .

[15] Helpman, E. (1984). "A simple theory of international trade with multinational corporations" Journal of Political Economy, 451-471.

[16] Hayashi, Fumio, (1982). "Tobin's Marginal q and Average q: A Neoclassical Interpretation," Econometrica, 50, 213-224.

[17] Khanna, S. (2014). "State-Owned Enterprises in India: Restructuring and Growth" Copenhagen Journal of Asian Studies, 30(2), 5-28.

[18] Lim, W., and Hahm, J. H. (2004). Financial globalization and Korea's post-crisis reform: A political economy perspective. Korea Development Institute.

[19] Lucas Jr, R. E. (1993). Making a miracle. Econometrica: Journal of the Econometric Society, 251-272.

[20] Lucas,R. E., Jr. and Prescott, E, C,. "Investment under Uncertainty," Econometrica, 39, 659-681, (1971).

[21] Meyer, K, E. (2004). "Perspectives on multinational enterprises in emerging economies" Journal of International Business Studies, 35, 259-276.

[22] Markusen, J. R. (1984). Multinationals, multi-plant economies, and the gains from trade. Journal of international economics, 16(3-4), 205-226.

[23] Park, J. and Park, S. (2011). "Privatization of state owned enterprises in Korea: Performance assessment and policy direction," Working Paper Series: Korea Institute of Public Finance,.

[24] Pindyck, R, S., "Irreversible Investment, Capacity Choice, and the Value of the Firm" American Economic Review, 78, 969-985, (1988).

[25] Sembenelli, A., and Siotis, G. (2008). "Foreign Direct Investment and mark-up dynamics: Evidence from Spanish firms" Journal of International Economics, 76(1), 107-115.

[26] Tobin, J., "A General Equilibrium Approach to Monetary Theory," Journal of Money, Credit, and Banking, 1, 15-29, (1969).

[27] Trevino, L. J., Thomas, D. E., \& Cullen, J. (2008). The three pillars of institutional theory and FDI in Latin America: An institutionalization process. International Business Review, 17(1), 118-133.

[28] U.S. Bureau of Economic Analysis., "An introduction to the national income and product accounts"Methodology papers: U.S. National Income and Product Accounts September, (2007).

[29] Vernon, J., "The international aspect of state- owned enterprises" Journal of International Business Studies, 10, 7-15, (1979).

[30] Wang, J., and Wang, X. (2015). "Benefits of foreign ownership: evidence from foreign direct investment in China" Journal of International Economics, 97(2), 325-338. 